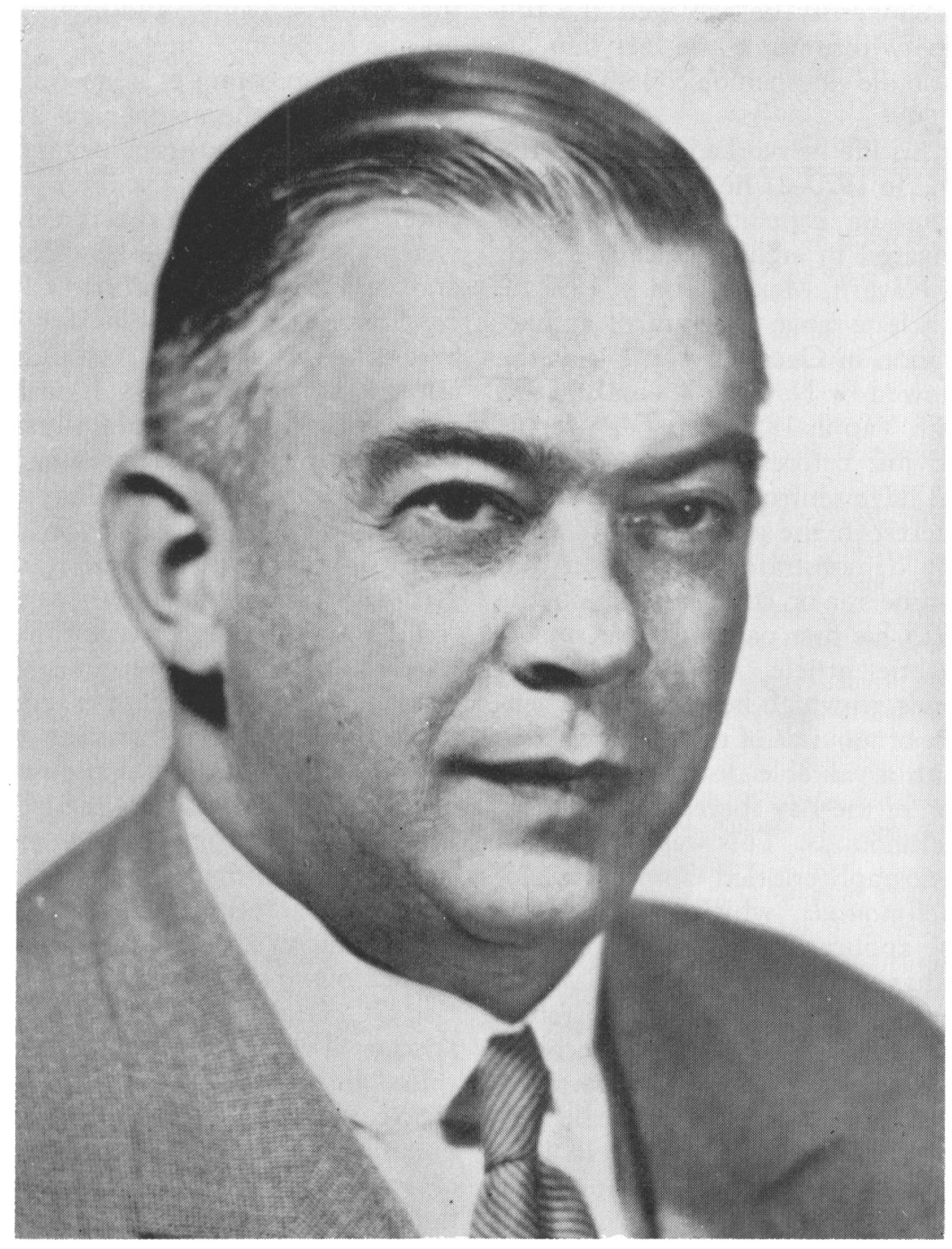

\title{
EDWARD WINSLOW GIFFORD - 1887-1959
}

Edward Gifford, who died at Chico, California, on May 16, 1959 at the age of 71, was one of those rare anthropologists who ranged over the broad field and made important contributions in archaeology, mythology, ethnology, kinship, and physical anthropology. In addition to these wide interests, on each of which he wrote substantial monographs, he was a conchologist and ornithologist of note.

From 1904 to 1912 he served as Assistant Curator of Ornithology in the California Academy of Sciences. From 1912 until his retirement in 1955 as Director, he was attached to the Museum of Anthropology at the University of California. In addition to his Museum duties, he was a teacher and during the 43 years of his connec- 
tion with the University he achieved the full professorship notwithstanding the fact that his formal education did not include college attendance.

Throughout his life he worked mainly in the California area. In 1920-21 he was in charge of the Bishop Museum expedition to Tonga; in 1945-46 he engaged in archaeological research in Sonora and Nayarit, Mexico; and in 1947 he embarked on a long-range program of archaeological excavation in Oceania with Fiji as the beginning, followed by New Caledonia in 1952 and ending with Yap in 1956. The Yap report was completed just before his death. Had he lived he would have returned to the Fiji group.

Gifford's interest in the archaeology of California is amply demonstrated by the fact that he published nine major contributions on the subject. In 1915 his first paper on the subject appeared in a brief article, The San Francisco Bay Shellmounds, in which he presented a general description of mounds of the San Francisco Bay region, with a valuable discussion of probable population of the Bay shore, and the composition of shellmounds. This was followed in 1916 by a monograph entitled Composition of California Shellmounds, which was the first example of the application of a sampling technique which has since become more widely used for determining the constituents of refuse deposits. In this paper the prehistoric ecology is determined and an effort is made to compute the age of shellmounds by estimating the rate of accumulation of the refuse deposits. In 1926 there appeared three papers which treated with prehistoric California materials. First is Californian Anthropometry, a major compilation of all available data concerning the physical anthropology of the living California Indians, as well as of all available archaeological skeletal remains. A very useful summary of this large work was printed under the title California Indian Types in the same year. Also in 1926 Gifford with W. E. Schenck, then Research Associate of the Department of Anthropology, studied local collections as well as materials in the University Museum of Anthropology and in their joint Archaeology of the Southern San Joaquin Valley blocked out the major outlines of the prehistory of the area. Gifford and Schenck succeeded in indicating the relative age of various sites and artifacts types, and concluded that all evidence noted by them dates from the later prehistoric period, but believed that earlier remains could occur in the area and may be found in future.

Gifford's program of a systematic survey and description of the archaeological collections of the Museum of Anthropology is first mentioned in print in his article, Typology for Archaeology, published in 1939. In this is a discussion of his system of typological designations using a letter and number code and illustrated with data and conclusions reached by him in his study of shell and bone artifacts from California. He points out the importance of typological cognates used in effecting crossdating, and illustrates this with reference to shell bead types manufactured on the California coast and found in Southwestern archaeological sites. One year later, in 1940, there appeared the volume Californian Bone Artifacts. Important in this work is the attention paid to changes of type through time insofar as these can be determined from materials deriving from stratified sites. Also of interest in this report is the comparison of all types represented in mounds of various areas, such as Sacramento Valley, Delta region, San Francisco Bay, South Coast region. At the end of this work Gifford provides the details of the occurrence of Californian shell artifact types from Southwestern sites, a subject to which he returned in two articles appearing in 1949 entitled Early Central Californian and Anasazi Shell Artifact Types and The Cochise Culture Olivella. In the same year Gifford published an article, Diet and Age of Californian Shellmounds, in which he compares the constituents of Fijian and San Francisco Bay shellmound deposits and discusses various possibilities to account for the differences in amount of bone and shell found in the coastal shell heaps in the two areas.

His contributions to Mexican archaeology were published in 1946, 1950, 1952, and 1953. Of these the Surface Archaeology of Ixtlan del Rio, Nayarit is the most substantial.

All three of the Oceanian excavations were major efforts, and the reports on Fiji, New Caledonia, and Yap are models of careful and complete reporting which set a new high standard for the area.

Gifford was one of the most warmly-loved men in the profession. Kind and always considerate, he was outgoing and friendly. He was a confidant and helper to his students, and always eager to discuss the current research problems of his colleagues. His personal ac- 
quaintance with California Indians numbered many hundreds, and few ethnographers have been more generously received and longer remembered by as many informants than Gifford. The present anthropological collections at Berkeley (which are at the moment being installed in a spacious new building) were amassed and cared for during his tenure and they will stand as an enduring record of his devotion to the principle that both the past and the future are a part of current anthropology.

The following bibliography is of Gifford's publications on archaeology and represents about one-fifth of his total writings.

\section{Robert F. Heizer}

1915 The San Francisco Bay Shellmounds. California Out-of-Doors, Vol. 1 (April), p. 29. San Francisco.

1916 Composition of California Shellmounds. University of California Publications in American Archaeology and Ethnology, Vol. 12, No. 1, pp. 1-29. Berkeley.

1926 California Indian Types. Natural History, Vol. 26, No. 1, pp. 50-6C. New York.

Californian Anthropometry. University of California Publications in American Archaeology and Ethnology, Vol. 22, No. 2, pp. 217-390. Berkeley.

Archaeology of the Southern San Joaquin Valley, California. With W. E. Schenck. Uniqersity of California Publications in American Archaeology and Ethnology, Vol. 23, No. 1, pp. 1-122. Berkeley.

1928 Pottery-Making in the Southwest. University of California Publications in American Archaeology and Ethnology, Vol. 23, No. 7, pp. 353-73. Berkeley.

1935 Note on Pottery-making in the Southwest. American Anthropologist, Vol. 37, No. 3, p. 535. Menasha.

1937 Stoppers or Modeling Tools. American Antiquity, Vol. 2, No. 3, p. 207. Menasha.

1940 Californian Bone Artifacts. University of California Anthropological Records, Vol. 3, No. 2, pp. 153237. Berkeley and Los Angeles.

1946 Archaeology of the Punta Peñasco Region, Sonora. American Antiquity, Vol. 11, pp. 215-21. Menasha.
1947 Californian Shell Artifacts. University of California Anthropological Records, Vol. 9, No. 1, pp. 1-132. Berkeley and Los Angeles.

1948 Typology for Archaeology. Vigesimoséptimo Congreso Internacional de Americanistas, Actas de la Primera Sesión, Celebrada en la Ciudad de México en 1939, Tomo 2, pp. 7-11. Mexico.

1949 Diet and the Age of Californian Shellmounds. American Antiquity, Vol. 14, No. 3, pp. 223-4. Menasha.

Early Central Californian and Anasazi Shell Artifacts Types. American Antiquity, Vol. 15, No. 2, pp. 156-7. Menasha.

The Cochise Culture Olivella. With D. S. Gifford. American Antiquity, Vol. 15, No. 2, p. 163. Menasha. Excavations in Viti Levu. Journal of the Polynesian Society, Vol. 58, pp. 83-90. Wellington.

1950 Surface Archaeology of Ixtlán del Río, Nayarit. University of California Publications in American Archaeology and Ethnology, Vol. 43, No. 2, pp. 183-302. Berkeley and Los Angeles.

1951 Archaeological Excavations in Fiji. Uniqersity of California Anthropological Records, Vol. 13, No. 3, pp. 189-288. Berkeley and Los Angeles.

A Program for Micronesian Archaeology. With K. P. Emory and others. American Anthropologist, Vol. 53, No. 4, pp. 594-7. Menasha.

1952 Archaeological Sites on Opposite Shores of the Gulf of California. With W. E. Schenck. American Antiquity, Vol. 17, No. 3, p. 265. Salt Lake City. A Carbon-14 Date from Fiji. Journal of the Polynesian Sociey, Vol. 61, Nos. 3-4, p. 327. Wellington. Expédition Archéologique de l'Université de Californie en Nouvelle-Calédonie. With Dick Shutler, Jr. Etudes Mélanésiennes, n.s., $5^{\mathrm{e}}$ année, No. 7, pp. 19-24. Noumea.

$1953 \operatorname{Re}$ Archaeology of the Galapagos Islands. American Antiquity, Vol. 19, No. 2, p. 171. Salt Lake City.

L'Archéologie Néo-Calédonienne en 1952. Journal Société des Océanistes, Vol. 9, pp. 64-70, 73-4. Paris.

1955 Six Fijian Radiocarbon Dates. Journal of the Polynesian Society, Vol. 64, p. 240. Wellington.

1956 Archaeological Excavations in New Caledonia. With Dick Shutler, Jr. University of California Anthropological Records, Vol. 18, No. 1, p. 1-148. Berkeley and Los Angeles. 